\title{
The Efficiency and Public Transport Accessibility of Indirect State Administration in the Czech Republic
} Iveta Vrabková, Ivana Vaňková, ${ }^{1}$ Igor Ivan $^{2}$

\begin{abstract}
This paper examines the efficiency and public transport accessibility of indirect (devolved) state administration performed by municipalities with extended powers (hereinafter MEPs) in the Czech Republic. Our aim is to evaluate the efficiency of the revenues made by municipalities with extended powers, through performing powers delegated to them by the state administration, and those municipalities' public transport accessibility as of 31 December, 2014. The rate of efficiency is tested on an output-oriented Free Disposable Hull model. One input variable is selected - the operating expenses of the municipal offices recalculated per inhabitant of the municipality's administrative district - and two output variables are selected: contribution to the performance of state administration, recalculated per inhabitant of the municipality's administrative district, and revenues from administrative fees per inhabitant of the municipality's administrative district. The municipality's offices' transport accessibility is evaluated via network analysis using ArcGIS software. The article investigates the hypothesis that public administration deconcentration practices logically result in higher security costs and therefore inefficiency. The results reveal that only 66 of the country's 205 MEPs are efficient and that operating expenses and state contributions for the performance of state administrative tasks play a significant role in these results. Efficiency is less significantly influenced by administrative fee revenues. Public transport accessibility is analyzed for two time intervals - 6:00 to 8:00 am and 1:00 to 2:00 pm - on Tuesdays. The degree of accessibility is defined using a six-point scale of accessibility. The results show that the best accessibility is in the morning hours, when the offices are accessible for $68.8 \%$ of the population aged $15+$ in the Czech Republic; the worst accessibility is in the afternoon hours when only $2 \%$ of the population aged $15+$ can access the offices.
\end{abstract}

Key words: Efficiency, public transport accessibility, state administration, municipality with extended power, Model Free Disposable Hull.

JEL Classification: H67, H71, H76

Received: 9 October 2015 / Accepted: 16 March 2016 / Sent for Public.: 16 June 2016

\footnotetext{
1 VŠB - Technical University of Ostrava, Faculty of Economics, Department of Public Economics, iveta.vrabkova@vsb.cz, ivana.vankova@vsb.cz

2 VŠB - Technical University of Ostrava, Faculty of Mining and Geology, Institute of Geoinformatics, igor.ivan@vsb.cz

(C) 2016 by the authors; licensee Review of Economic Perspectives / Národohospodářský obzor, Masaryk University, Faculty of Economics and Administration, Brno, Czech Republic. This article is an open access article distributed under the terms and conditions of the Creative Commons Attribution 3.0 license, Attribution - Non Commercial - No Derivatives.
} 


\section{Introduction}

In the Czech Republic, state administration is organised on two levels. The first consists of direct state administration exercised by government authorities at both a state and district/local level. The second consists of indirect state administration exercised on legal authority by non-state legal and private entities (Hendrych, Kavěna, Pavlík, 2014). The majority of this latter, indirect, state administration is performed by municipal and regional authorities as delegated powers.

This state administration model was introduced on 1 January, 2003, when 205 municipalities were granted extended powers in the 2nd stage of a major public administration reform. These municipalities with delegated powers provide a wide range of civil services, including hearing traffic offences, issuing ID cards and passports, and performing various tasks related to the social and legal protection of children. The municipalities with extended powers are determined by law (Act No. 314/2002) and regulated by the Ministry of the Interior of the Czech Republic (Decree No. 388/2002). The costs of providing these services are charged to the municipality in question, and the government partially compensates these costs via a fixed contribution whose value is set by the State Budget Law via an annual contribution algorithm which takes into account the type of municipality (the extent of its delegated powers, the popupation of its administrative district and administrative centre), and a macroeconomic prediction for the Czech Republic, including tax revenues. Many changes have been made to these fixed contributions since 2003, in response to practical demands from the municipalities and careful targeting by the state so as to create an effective financial instrument. However, there is still some debate over the optimal level of contributions in relation to the real services provided by (and costs incurred by) the municipalities with extended powers (Ministry of the Interior of the Czech Republic, 2015; Ministry of th Interior of the Czech Republic, 2012). The non-homogenous size structure of these municipalities in terms of the number of inhabitants in their administrative centres (hereinafter ACs) and number of inhabitants in their administrative districts (hereinafter ADs) represents a limiting factor for the optimal assessment of contributions, Previous research (Provazníková, Petr, 2014; Toth et al., 2009) has looked at the system of financing for MEPs relative to the size of their ADs and designed calculations for appropriate contributions to cover the powers delegated to them by the central state administration.

This article's first aim is to evaluate the efficiency of the revenues collected by municipalities with extended powers in relation to their performance of the powers delegated to them by the central state administration, compared with the expenses the municipalities incurred for the operation of their offices up to 31 December, 2014.

We test the efficiency rate of the municipalities' key revenues associated with their delegated powers from the central state administration using the Free Disposable Hull model (hereinafter FDH). The revenues tested include state contributions and revenues from administrative fees; these are compared with the municipalities' operating expenses. The FDH method only evaluates each unit of the file in relation to the other units relatively, unlike Data Envelopment Analysis models (hereinafter DEA), (Jablonský, Dlouhý, 2004). Methods based on multi-criteria decision-making models 
such as DEA and FDH have been used to assess efficiency in the public sector by many researchers, both foreign (Deprins, Simar, Tulkens, 1984; Jacobs, 2001; Simpson, 2009; Vakkuri, 2003) and Czech (Borůvková, Kuncová, 2012; Dlouhý, Jablonský, Novosadová, 2007; Dlouhý, 2009; Jablonský, Grmanová, 2009; Vaňková, Vrabková, 2014). However, their studies have so far not focused on public administration.

The existence of municipalities with extended powers is associated with the principle of subsidiarity. In this case that takes the form of vertical devolution of government powers, with the aim of improving local availability of aspects of state administration that are focused on citizens' most frequent situations. Availability is not to be understood as a concept of qualitative and quantitative importance, to which can be viewed from multiple angles. So availability takes economic, institutional, temporal or spatial dimension.

Secondly, this article evaluates the public transport accessibility of the relevant municipalities' central offices as of 16 December, 2014.

As part of this paper, we assess the availability of these devolved services in terms of the public transport accessibility of each municipality's central offices. The starting point for our evaluation of transport accessibility is, in line with Hay (2000), a quantitative assessment of transport networks using network analysis, which reports accessibility (accessibility to points of transport and hubs), connectivity (continuity, the interconnection of transport networks) and deviatility (the transport route's rate of deviation from the shortest route possible).

The municipal offices' spatial accessibility within the public transport network is analysed using a developed database of public transport connections and geographic information systems.

Both aims are complementary and together provide a unique analytical evaluation of municipalities with extended powers.

\section{Municipalities with extended powers}

Between 1998 and 2000 a reform of the public administration system in the Czech Republic was designed and prepared. For organisational reasons, this was divided into two phases. During the first phase, autonomous regional authorities were formed, and during the second phase district offices that were approved by the concept of excess. 72 district offices were replaced by 205 municipalities with extended powers (hereinafter MEPs) which were established on January 1, 2003. The cities of Ostrava, Brno, Plzeň and Prague were granted a special regime, wherein matters previously handled by district authorities were now to be exercised by the city authorities. The geographical areas to be served by the district offices and the new MEPs were defined by the territories of the constituent 76 districts. Today's model of 205 municipalities with extended powers was proposed by the government; an opposing motion was filed on 27 February, 2002 by the Committee on Public Administration, Regional Development and Environment of the Chamber of Deputies (see Resolution No. 304, Bill No. 1159), 
which recommended that the municipalities with extended powers should be the municipalities in which district authorities were located, as of 31 December, 2002.

The establishment of the MEPs created 205 new administrative districts according to Decree No. 388/2002 of the Ministry of the Interior of the Czech Republic, on the establishment of administrative districts for municipalities with authorised municipal offices and administrative districts for municipalities with extended powers. It is worth mentioning that (as of 31 December, 2014) the Czech Republic has 6,253 municipalities in total, 214 of which are townships, 576 towns and 25 corporate towns. The 205 MEPs are substantially varied territorial administrative units, particularly in terms of the population of the towns where their offices are located (their administrative centres) and the populations of the administrative districts they serve. There are also considerable disparities amongst these units in terms of the land area of the districts they serve: the largest territory is the Znojmo $\mathrm{AD}$, with an area of $1,242 \mathrm{~km}^{2}$, while the smallest is the Český Těšín AD with an area of $44.42 \mathrm{~km}^{2}$. It is important to note that the MEPs' administrative districts encompass varying numbers of municipalities; there are 111 municipalities served by the Znojmo MEP while the Brno MEP serves just a single municipality (see details in Figure 1).

\section{Figure 1: Box plots of population and area (in $\mathrm{km}^{2}$ ) of MEPs (in 2014)}
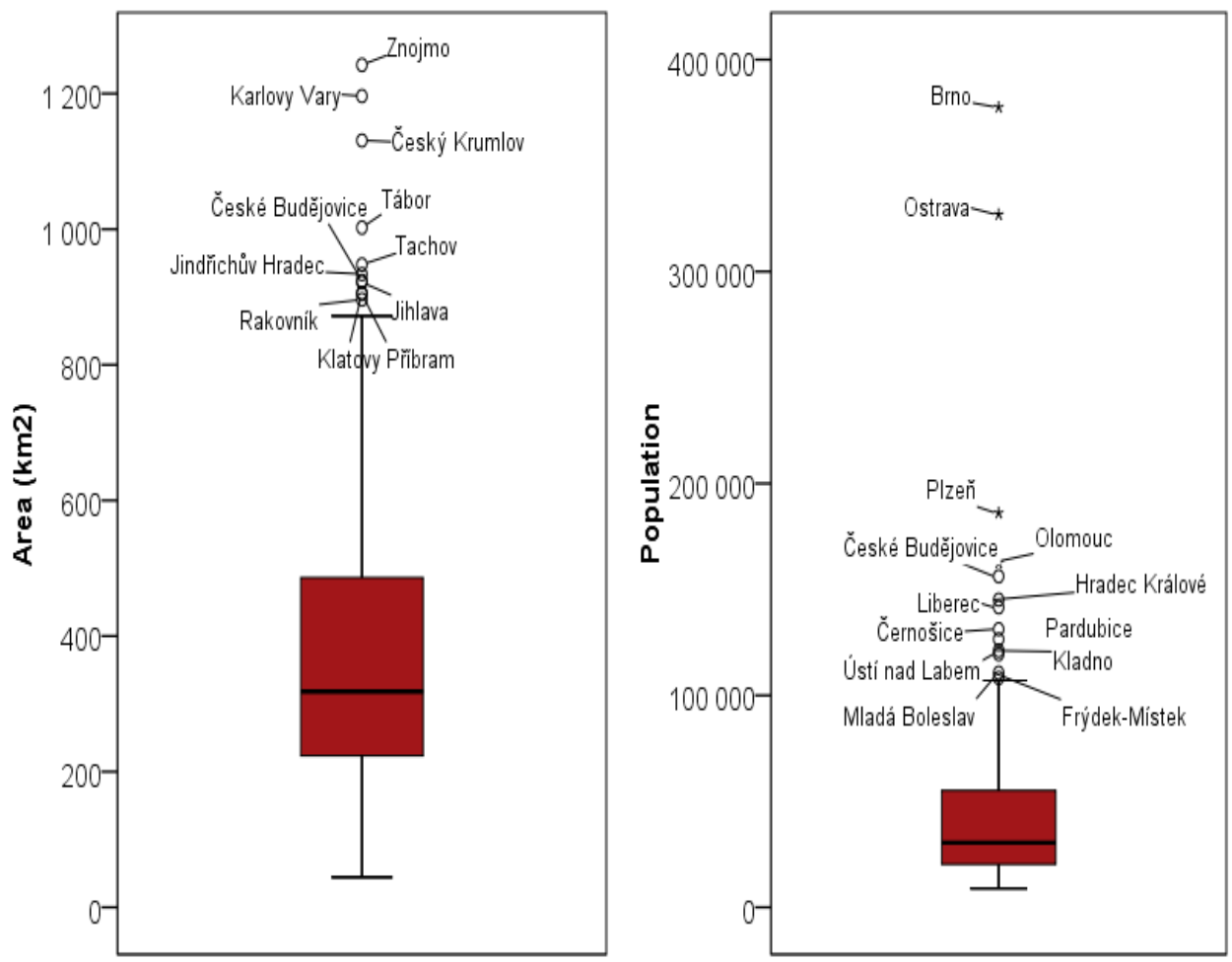

Source: CZSO. (2015). Small Lexicon of Municipalities of the Czech Republic. Authors. 
Most powers delegated by the central government authorities are exercised by local authorities and municipalities, which are the administrative bodies of the municipalities with extended powers. The administrative activities concerned include, for example, matters concerning the organization of elections, citizenship, trade, transport, internal governance, social affairs and regional development.

The MEPs' territorial administrative units can be classified in various ways; first, we can look at what share of the population of their administrative district (AD) is found in their administrative centre (AC). Second, we can divide the MEPs into five groups (designated I, II, III, IV, V) by the population of their AD Group I is composed of 15 MEPs serving a population $\geq 100,000$ inhabitants; group II is composed of 45 MEPs serving a population between 50,000 and 100,000 inhabitants; group III is composed of 43 MEPs serving a population between 30,000 and 50,000 inhabitants; group IV is composed of 54 MEPs serving a population between 20,000 and 30,000 inhabitants; group V is composed of 48 MEPs serving a population < 20,000 inhabitants.

These group classifications by population in the MEPs' administrative districts will be used in our analysis of efficiency using the FDH model and in our analysis of accessibility using network analysis.

\subsection{State contributions for the performance state administrative tasks, and administrative fees}

The contributions paid from the State Budget to municipalities in recognition of them performing delegated tasks is stipulated by the Law on Municipalities. These contributions are calculated in each calendar year as part of the State Budget, using a method that takes into account the extent of the delegated powers, the population of the administrative district, and in the case of MEPs the population of the administrative centre.

The procedure to determine the contribution to each municipality for its personal and material expenses related performing state administration tasks did not change in the period 2003-2005, although the amounts of the contributioons changed. In this period, the contributions were calculated based on the municipalities' number of inhabitants as a share of the total population in the Czech Republic as on 1 January of the previous year. The value of the contribution was then a multiple of a fixed-rate contribution for every 100 inhabitants permanently living in the territory served by the municipal authority, i.e. per one hundredth of the total population of the territory. The fixed contribution rates were dependent on the extent of delegated or transferred state powers to the municipality in question. In 2006, this procedure changed because the method of financing that had been in use was considered only a temporary (transformation) solution to ensure objective distribution of funds to municipalities with extended powers and other authorities and to facilitate the delimitation of employees at the district offices.

Municipalities that did not have extended powers continued to receive funding based on a contribution per 100 inhabitants - the system all the same. This means that small municipalities were undervalued, and large municipalities overvalued. Meanwhile, a 
new system of financing for municipalities with extended powers was introduced, involving functional positions, which made the system of determining contributions for state administrative tasks inconsistent. The gap in the relative amount of funding for state administrative tasks received by municipalities with extended powers (whose contributions from the State Budget covered approx. 90\% of their expenses) and other municipalities (whose contributions covered less than $50 \%$ of their expenses) increased.

For 2006, therefore, the methodology for establishing the contributions was updated, partly due to some changes in the administrative districts served by some authorities exercising delegated powers (e.g. the registry and building offices) and on the basis of a detailed analysis of expenses and revenues related to state administrative services provided by municipalities with authorized municipal offices and by municipalities with extended powers. Municipalities were divided into 3 groups: municipalities, municipalities with extended powers and special status, and municipalities with extended powers and an extraordinary contribution. The same rules continued to apply in 2007, 2008 and 2009. In 2010 there was a change to the the division of municipalities into groups, forming four groups: the first group consisted of municipalities (without extended powers), the second group included municipalities with extended powers, the third group consisted of municipalities with extended powers and special status, and the fourth group included municipalities with extended powers and an extraordinary contribution. This division was used until 2013.

For 2014, contributions for the exercise of delegated powers are defined in Amendment No. 8 of Act No. 475/2013 CL, on the state budget for 2014. This Amendment describes the procedure for determining the amount of these contributions for individual municipalities and for the capital city of Prague.

For MEPs, the contributions are calculated as a sum of two amounts, which are calculated using formula P1 (1) and formula P2 (2). In selected municipalities (MEPs with special status), the resulting amount is then increased by a specific amount as defined in Amendment No. 8 of the Law on the State Budget. The municipalities with this special status are Brandýs nad Labem - Stará Boleslav, Černošice, Nýřany, Šlapanice, Brno, Ostrava and Plzeň.

$$
\begin{aligned}
& P 1=\frac{B}{A+\sqrt{A D}} x A D \\
& P 2=C x\left(1-\frac{A C}{A D}\right) \times A D
\end{aligned}
$$

$\mathrm{A}, \mathrm{B}$ and $\mathrm{C}-$ coefficients for the extent of the municipality's delegated competencies, $\mathrm{AD}$ - the number of inhabitants in the administrative district, $\mathrm{AC}$ - the number of inhabitants in the administrative centre.

These state contributions are intended to partly cover the expenses incurred by the municipalities in relation to their provision of state administrative services. These expenses primarily consist of payroll and operating expenses linked to the staff who 
provide those services. One-time costs, such as the acquisition of tangible and intangible assets, are not considered relevant for the purposes of this contribution.

An analysis of the contributions provided from the State Budget in 2014 to municipalities exercising delegated powers is shown in Figure 2. The figure shows the contributions for 2014 recalculated per inhabitant of the given AD. Seen from this perspective, the smallest MEPs received the highest contributions - these were Králíky, Pacov and Konice - while larger MEPs Černošice, Chrudim and Liberec received the lowest contributions.

Figure 2 Government contribution to municipalities' performance of state administrative tasks, recalculated per inhabitant of each administrative district and presented by, municipal groups based on size of administrative centre, year 2014, in CZK

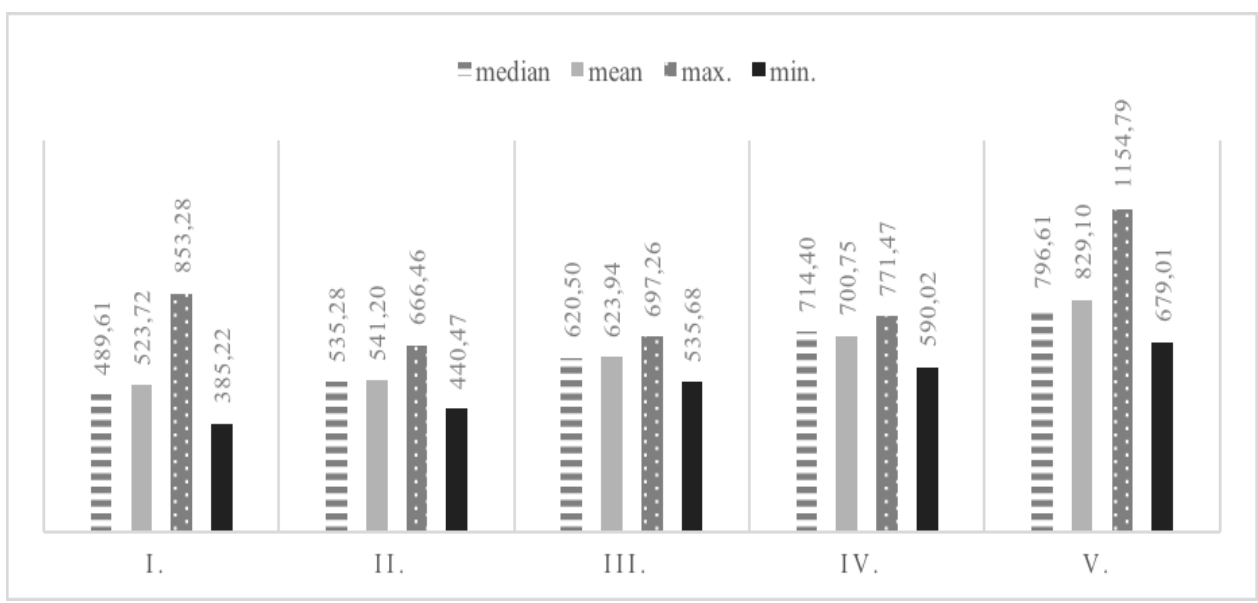

Source: Ministry of Finance of the Czech Republic. (2015). Monitor. Authors.

The difference between the maximum and minimum figures and the level of determinative deviation in the contributions (recalculated per AD inhabitant) confirm that $31 \%$ of MEPs in Groups I and V have a higher variability rate or rather variational range, compared to $69 \%$ of MEPs in Groups II, III, and IV.

Although these contributions represent a key source of income, MEPs also fund their performance of state administrative services from other revenues of the State Budget; for example, activities carried out by municipalities with extended powers in the field of social and legal protection of children are covered through chargeable subsidies. Billing is based on the number of cases the municipalities register and on the municipalities' actual expenditures on this agenda. The system is overseen by the Ministry of Labour and Social Affairs of the Czech Republic, while the funding itself is processed by the Ministry of Finance. All activities related to elections are also covered separately from the main financial contribution: municipal expenditures associated with preparing and holding elections are covered from the General Public Administration chapter of the 
State Budget of the Czech Republic for the relevant year. Targeted subsidies for expenses related to elections are provided to the municipalities via their regional authorities. Furthermore, municiplities' delegated activities in the field of fire protection are covered above and beyond the contribution, as the Ministry of the Interior of the Czech Republic provides targeted non-investment subsidies to regional authority budgets and to capital city of Prague.

When providing state administrative services, municipalities collect administrative fees. which become budget revenue for those municipalities and can be used to cover the costs of the service provision. These administrative fees are established through an administrative procedure laid down in special legislation: transactions subjected to charges are defined individually in the Scale of Fees that forms an Amendment to Act No. 634/2004 of CL, on administrative fees. Many administrative acts are subject to such administrative fees (e.g. accepting applications, issuing permissions, certificates and licences). The fee payers are natural or legal persons who make use of such services from the administrative authority, or persons on whose behalf these services are used.

The volume of administrative fees collected annually by a particular authority may be assessed as a partial factor in evaluating the MEPs' performance of administrative activities. Figure 3 below compares four different MEP size groups according to their administrative fee revenues per $\mathrm{AD}$ inhabitant, presenting the median, mean, maximum and minimum values of administrative fees collected per inhabitant of the relevant municipalities' administrative districts.

The median and mean values shown in Figure 3 demonstrate that administrative fee revenues per capita are rather comparable between the various groups of MEPs.

Figure 3 Revenues from administrative fees recalculated per inhabitant of the MEP's administrative district, presented by MEP groups based on size of administrative district, year 2014, in CZK

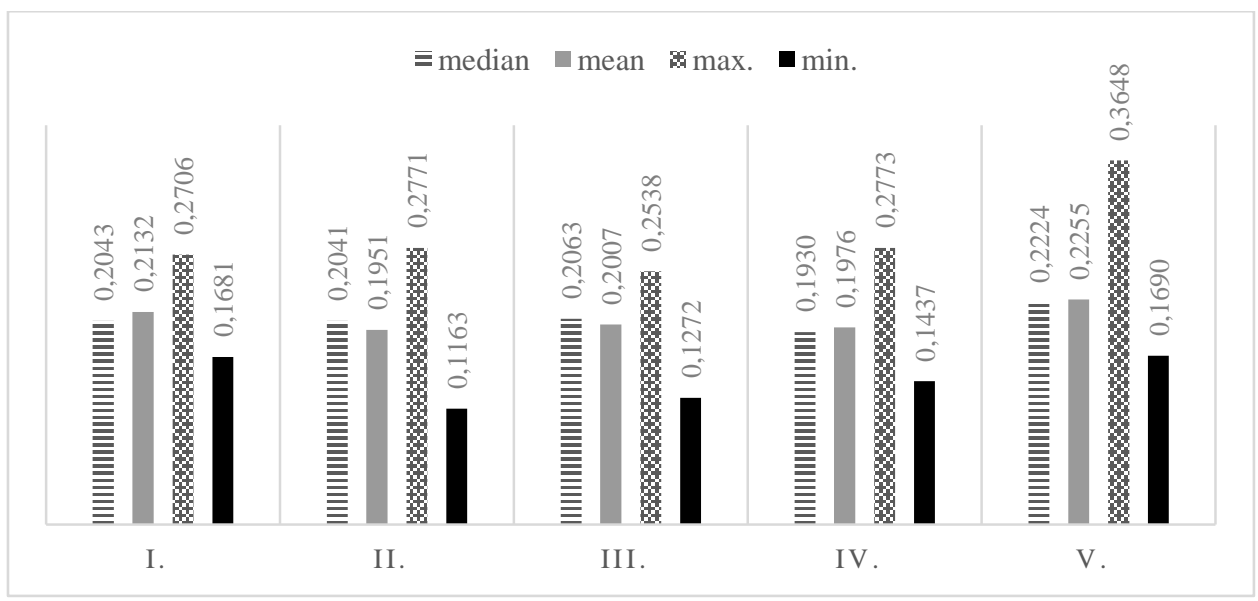

Source: Ministry of Finance of the Czech Republic. (2015). Monitor. Authors. 


\subsection{MEP office operating expenses}

As part of our efficiency model, we take into account the MEPs' office operating expenses. These expenses are defined by Act. No. 250/2000 Coll., on budgetary rules of territorial budgets (as last amended, economic classification secton 6171) and consist of expenses for the municipalities' employees' salaries and mandatory social security and health insurance contributions, expenditures for the purchase of services (power, communications, education, travel), and for material purchases (office supplies, IT, etc.) Data on these expenditures was obtained from a public database held by the Ministry of Finance of the Czech Republic, entitled MONITOR. From the total expenditures, we then calculated the expenditures per inhabitant of each MEP's administrative district. Expenses associated with local government offices were not excluded from these figures because the authorities themselves do not record these expenses separately and so cannot report them separately. The ratio of delegated state administrative tasks and independent local administrative tasks in relation to a given authority's expenditures is complicated both where small offices frequently combine activities in both areas within a single workload and where larger offices do not clearly distinguish between these two areas. For example, employees in the fields of accounting, human resources, legal services, information and communications exercise these activities for the benefit of all office staff - both those involved in local administrative duties and those performing delegated state administrative duties. Figure 4 reports operating expenditures for five MEP size groups; in terms of average expenditure, the difference between groups is less pronounced although the highest expenditures on administrative tasks are evidently among MEPs in the fifth size group.

Figure 4 MEP operating expenditures recalculated per inhabitant of their administrative district by MEP group based on size of administrative district, year 2014, in CZK

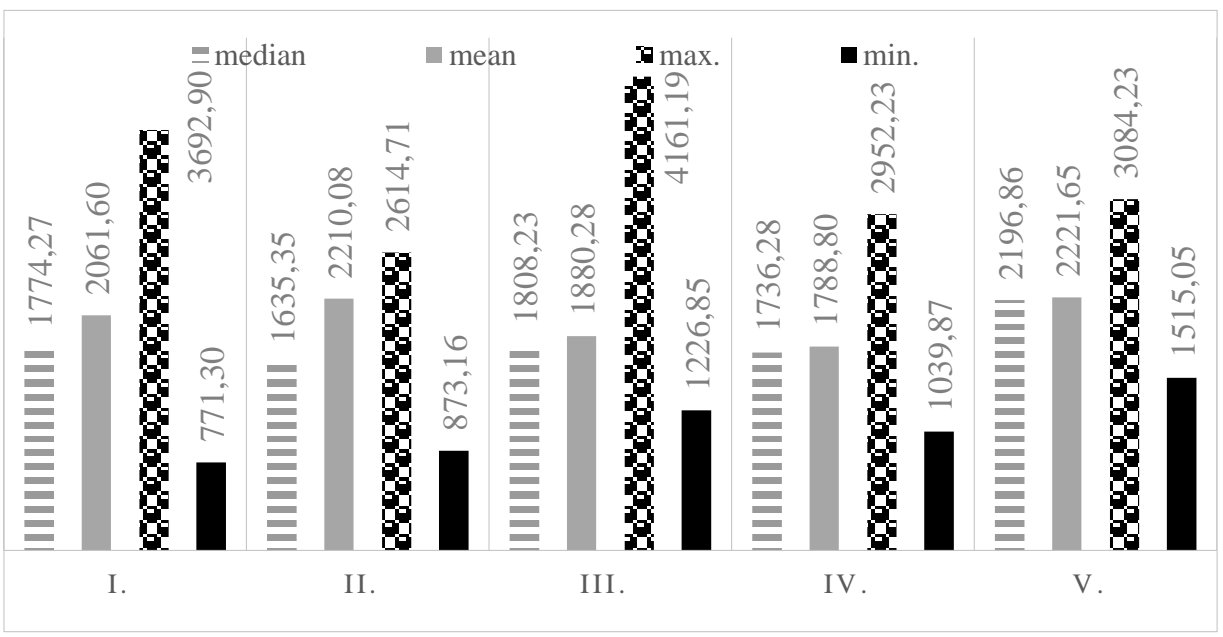

Source: Ministry of Finance of the Czech Republic. (2015). Monitor. Authors. 
It is interesting that the lowest expenses per capita of AD of CZK 771.30, were incurred by MEP Černošice, which is in the first size group. In contrast, the highest expenses in this size group were 3,692.90 CZK per capita in MEP Brno, followed by Ostrava and MEP Plzeň. The highest spending of any MEP was 4,161.19 CZK per inhabitant, in MEP Kralupy nad Vltavou, which belongs to the third size group.

\section{Methodology}

The methodology we have chosen in order to examine the issues outlined above is based on the needs of the identified targets (see Introduction). First, the MEPs' technical efficiency is tested using an output-oriented FDH model; second, the MEPs' offices' transport accessibility is simulated using a Network analysis and the ArcGIS software. The final part of our evaluation examines the possible relationship between effective/ineffective MEPs and accessible/less accessible MEPs.

\subsection{FDH model}

The Free Disposable Hull (FDH) model is a discrete model of production function. Its basic property is an inconvex set of production possibilities. Unlike DEA models, in FDH models each Decision Making Unit (DMU - in our case, each municipality with extended powers) can only be assessed relatively against other existing units, and not towards their convex combinations. The advantage of the FDH model is that the character of revenues is not limited by any preconditions. FDH models analyze both input- and output-oriented assignments. In this paper an output-oriented FDH model is applied.

Jablonsky and Dlouhý (2004) state that input- and output-oriented FDH models are tasks of mixed binary programming. A matrix of inputs and outputs $X$ and $Y$ represents the structural coefficients of a task; the model variables are vectors $\lambda, s+, s$ - and variable $\theta$ (in a model based on inputs) or $\Phi$ (in a model based on outputs), $\mathrm{e}^{\mathrm{T}}=(1,1, \ldots, 1), \varepsilon$ is an infinitesimal constant. To evaluate the efficiency of all the units the task $(3,4)$ must be resolved for each unit separately, ie. $n$-times. The value of the objective function measures the distance of the unit from production possibilities. Depending on the type of model orientation (input/output), the result indicates how much it would be necessary to increase outputs or decrease inputs in order for the production unit to be evaluated as effective.

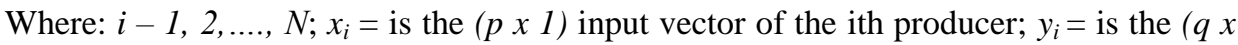
1) output vector of the ith producer; $X$ is an $(p x N)$ input matrix where $p$ is the number of inputs; $\mathrm{Y}$ is an $(q x N)$ output matrix where $q$ is the number of outputs.

The fractional formulation of an input-oriented FDH model is presented below:

minimize $\Phi-\varepsilon\left(e^{T} s^{+}+e^{T} s^{-}\right)$

subject to $Y \lambda-s^{+}=\Phi y_{q}$,

$$
X \lambda+s^{-}=x_{q},
$$




$$
\begin{aligned}
& e^{T} \lambda=1, \lambda \text { - binary, } \\
& s^{+} \geq 0, s^{-} \geq 0 .
\end{aligned}
$$

The general mathematical formulation for an output-oriented FDH model is:

maximize $\Phi+\varepsilon\left(e^{T} s^{+}+e^{T} s^{-}\right)$

subject to $Y \lambda-s^{+}=\Phi y_{q}$,

$$
\begin{aligned}
& X \lambda+s^{-}=x_{q}, \\
& e^{T} \lambda=1, \lambda \text { - binary, } \\
& s^{+} \geq 0, s^{-} \geq 0 .
\end{aligned}
$$

The FDH model tests whether the production unit is non-dominated or Pareto efficient. Pareto makes units effective when $\Phi=1$. If the variable $\Phi$ is $>1$, this result indicates that the production unit should increase its output values proportionally (e.g. $\Phi=1.08$ suggests that output parameters must be increased by at least $8 \%$ ) in order to become an effective production unit. Within this article one input and two outputs have been selected, see Figure 5.

\section{Figure 5 The scheme of the selected output-oriented FDH model}

\begin{tabular}{|c|c|}
\hline Input: & $\begin{array}{c}\text { Outputs: } \\
\text { Office operating expenses } \\
\text { recalculated per inhabitant of the } \\
\text { MEP's administrative district }\end{array}$ \\
$\begin{array}{c}\text { Contribution for performance of state } \\
\text { administrative tasks recalculated per } \\
\text { inhabitant of the MEP's administrative } \\
\text { district }\end{array}$ \\
$\begin{array}{c}\text { Revenues from administrative fees } \\
\text { recalculated per inhabitant of the } \\
\text { MEP's administrative district }\end{array}$ \\
\hline
\end{tabular}

Source: Authors

\subsection{Accessibility by public transport}

The accessibility of each MEP's offices by public transport was delimited using a database of public transport connections (Horák et al., 2014; Ivan, Horák, 2015). This database contains connections between all municipalities within 150 kilometres included in valid time tables (valid from December 2014) which meet the following conditions: 1) travel time is less than 90 minutes; 2) the connection involves five changes or fewer; 3) the arrival time cannot be earlier than 60 minutes before; 4) the departure time from an origin cannot be earlier than 120 minutes before arrival. In this paper, only connections arriving at their destinations between 6 and 8 a.m. or between 1 and 2 p.m. on a working day were considered. The specific connections considered were valid on Tuesday 16 December. A Tuesday was chosen because transport connections on Mondays and Fridays may vary from connections on other weekdays, due to 145 
weekend-related travel. The supply of transport connections on Tuesdays, Wednesday and Thursdays may be considered almost identical (Drdla, 2014; Murdych, 1998). From the list of connections that met our conditions, the best connection was selected based on a weighting function that compared travel time, time of arrival, time of departure, number of changes and price.

Each municipality is defined by a set of public transport stops (as, for example, in the online journey planner idos.cz). The destination (MEP) is defined as the administrative centre as a whole, rather than closest public transport stop to the offices themselves, because urban public transport was excluded from our calculations. The municipalities' service areas are delimited by public transport travel time (including transfer times or waiting times for connections). The threshold values for time intervals are defined as 10, 20, 30, 60 and 90 minutes. Only internal accessibility within each MEP's administrative region is analysed, so inter-municipal public transport connections were only considered within each administrative region separately, and not connections to other administrative regions' centres.

\section{Results}

\subsection{Results - the technical efficiency of MEPs}

The DMUs (MEPs) are divided into groups as before according to their size, and sorted according to their degree of efficiency - from the least efficient to the most efficient.

Where the test units are reported to be efficient, this means that they achieve their outputs in the form of contribution to the performance of delegated powers and revenues from administrative fees at the optimum input level in the form of operating costs.

A synthetic view of the results of the output-oriented FDH model is shown in Table 1. From the perspective of average efficiency rate, group I is the most efficient: this group consists of only $15 \mathrm{MEPs}$, and their average efficiency rate is $98.5 \%$. This group consists of the largest MEPs, including Brno and Ostrava, whose administrative districts all have populations of $\geq 100$ thousand. Group III comes second; this group consists of 43 MEPs with an average efficiency rate of $95.7 \%$. The population of their administrative districts is $\geq 30$ thousand. In third place is group IV consisting of 54 MEPs with an average efficiency of $95.3 \%$; these have administrative districts with populations of $\geq 20$ thousand. Group V is in fourth place; this is made up of 48 MEPs with administrative district populations of $<20$ thousand and an average efficiency rate of $90.1 \%$. The least efficient group is group II, consisting of 45 MEPs with administrative district populations $\geq 50$ thousand and an average efficiency rate of $86.2 \%$.

Table 1 also shows that the most inefficient DMU is MEP Uherské Hradiště, in Group II, with $\Phi=1.423$. This result indicates that this DMU should decrease its operating expenses at the current outputs (the amount of contributions and revenues from administrative charges per inhabitant of the administrative district) by $42.3 \%$ in order to 
be effective. The reduction in operating expenses required of the other inefficient units may be interpreted in the same manner.

Table 1 Efficiency results according to MEP size groups

\begin{tabular}{|l|c|c|c|c|c|}
\hline MEP groups by size of district & I & II & III & IV & V \\
\hline Number of units & 15 & 45 & 43 & 54 & 48 \\
\hline Number of effictive units $[\Phi=1]$ & 12 & 6 & 18 & 16 & 14 \\
\hline Number of inefficient units $[\Phi>1]$ & 3 & 39 & 25 & 38 & 34 \\
\hline Minimal efficiency rate & 1.056 & 1.423 & 1.207 & 1.171 & 1.351 \\
\hline Average efficiency rate & 0.015 & 1.138 & 1.043 & 1.047 & 1.099 \\
\hline Average efficiency rate in $\%$ & 98.5 & 86.2 & 95.7 & 95.3 & 90.1 \\
\hline Variability efficiency rate & 0.016 & 0.108 & 0.057 & 0.049 & 0.097 \\
\hline $\begin{array}{l}\text { Order according to average } \\
\text { efficiency }\end{array}$ & $\mathbf{1}$ & $\mathbf{5}$ & $\mathbf{2}$ & $\mathbf{3}$ & $\mathbf{4}$ \\
\hline
\end{tabular}

Source: Authors

The results of our test using the FDH model, with the selected input and output parameters, show that efficiency is not directly proportional to the size of an MEP's adminisrative district. With the exception of group I, we cannot say generally that larger MEPs utilize their state contributions and revenues from administrative fees more efficiently in the exercise of their delegated powers than smaller MEPs. The results suggest that most MEPs $(67.8 \%)$ should reduce their operating costs, in particular expenditure on salaries and office operation, in order to run efficiently.

These results also open up the question of what the right (optimal) contribution from the state to these municipalities to support their performance of delegated powers should be. Is that contribution currently too low and hence the majority of municipalities are suffering from inefficiency caused by providing state administrative services? Or is the contribution optimally high and the inefficiency results from municipalities' excessively high operating costs, indicating that they make wasteful use of public funds?

To test this, we tested seven MEPs (MEPs with so-called special status) using the same FDH model (see Figure 5), but with a lower the output variable - contribution for performance of state administrative tasks per inhabitant of the administrative district reduced by a specified amount (i.e. we removed an additional fixed contribution that these MEPs receive based on Act No. 475/2013 of CL, on the state budget of the Czech Republic in 2014).

We find that the MEPs' efficiency remained unchanged with the lower contribution in Černošice, Šlapanice, Nýřany and Brandýs nad Labem - Stará Boleslav. These are MEPs where the additional contribution is justified because part of the authority is located outside the MEP's administrative district (Šlapanice has some offices in Brno, 
Černošice and Brandýs nad Labem - Stará Boleslav have certain offices in Prague and Nýřany has some offices in Plzeň) and so these MEPs have increased operating expenses. These MEPs are still able to operate effectively with a lower contribution and an unchanged level of operating expenses and income from management fees. Conversely, the biggest MEPs: Brno, Ostrava and Plzeň would - if their additional contribution was removed - become ineffective. The result for Brno was $\Phi=1.12$, for Ostrava $\Phi=1.17$ and for Plzeň $\Phi=1.1$

\subsection{Results - the spatial accessibility of MEPs' offices}

The public transport accessibility of the MEPs' offices is simulated in two daily time periods, from 6:00 a.m. to 8:00 a.m. (see Figure 6) and from 1:00 p.m. to 2:00 p.m. (see Figure 7). Accessibility is defined by the time needed to reach the destination, in the following ranges:

- $\quad 1$ : excellent accessibility - journey time 0.1 - 10 minutes;

- 2: very good accessibility - journey time 10.1 - 20 minutes;

- 3: good accessibility - journey time 20.1 - 30 minutes;

- 4: poor accessibility - journey time 30.1 - 60 minutes;

- 5: very poor accessibility - journey time 60.1 - 90 minutes;

- 6: inaccessible - journey time more than 90 minutes, or no public transport connection available.

Both maps (Figures 6 and 7) define the borders of the MEPs' administrative districts, and within them individual municipalities' territories. These territories are shaded according to the journey time taken to reach the relevant MEP administrative centre from them. It is logical that accessibility is always the best in the MEP's administrative centre itself. Accessibility is also usually very good or good in the villages immediately adjacent to the central town. Worse accessibility is evident within municipalities situated close the borders of the MEPs' administrative districts, except when the districts only cover a small number of municipalities, such as in the Moravian-Silesian Region, Český Těšín, Karviná, Havírovov and Orlová MEPs. Accessibility is poorer in mountain territories close to the national borders of the Czech Republic, e.g. for Šmperk and Jeseník MEPs in the region of Olomouc. In some cases, MEPs have poor or very poor acceessibility due to the size (e.g. Zlín MEP) or shape of the administrative district they serve, e.g. Kutná Hora and Kroměříž MEPs. Another factor that influences the level of availability is the location of MEP's, main offices, eg. Černošice MEP has offices in Prague, while Šlapanice MEP has offices based in Brno.

Comparing Figure 6 and Figure 7, it is evident that MEP offices are more accessible via public transport in the morning than in the afternoon. Indeed in some administrative districts (those served by Sušice, Tachov, Šumperk and Př́ibram MEPs) there are a number of municipalities for whom the MEP offices are inaccessible in the afternoon hours (and this is not only a result of us considering a shorter -1 hour - time period in the afternoon, compared to the 2 hours in the morning). 
Figure 6: Accessibility of MEPs' offices by public transport between 6 and 8 a.m.

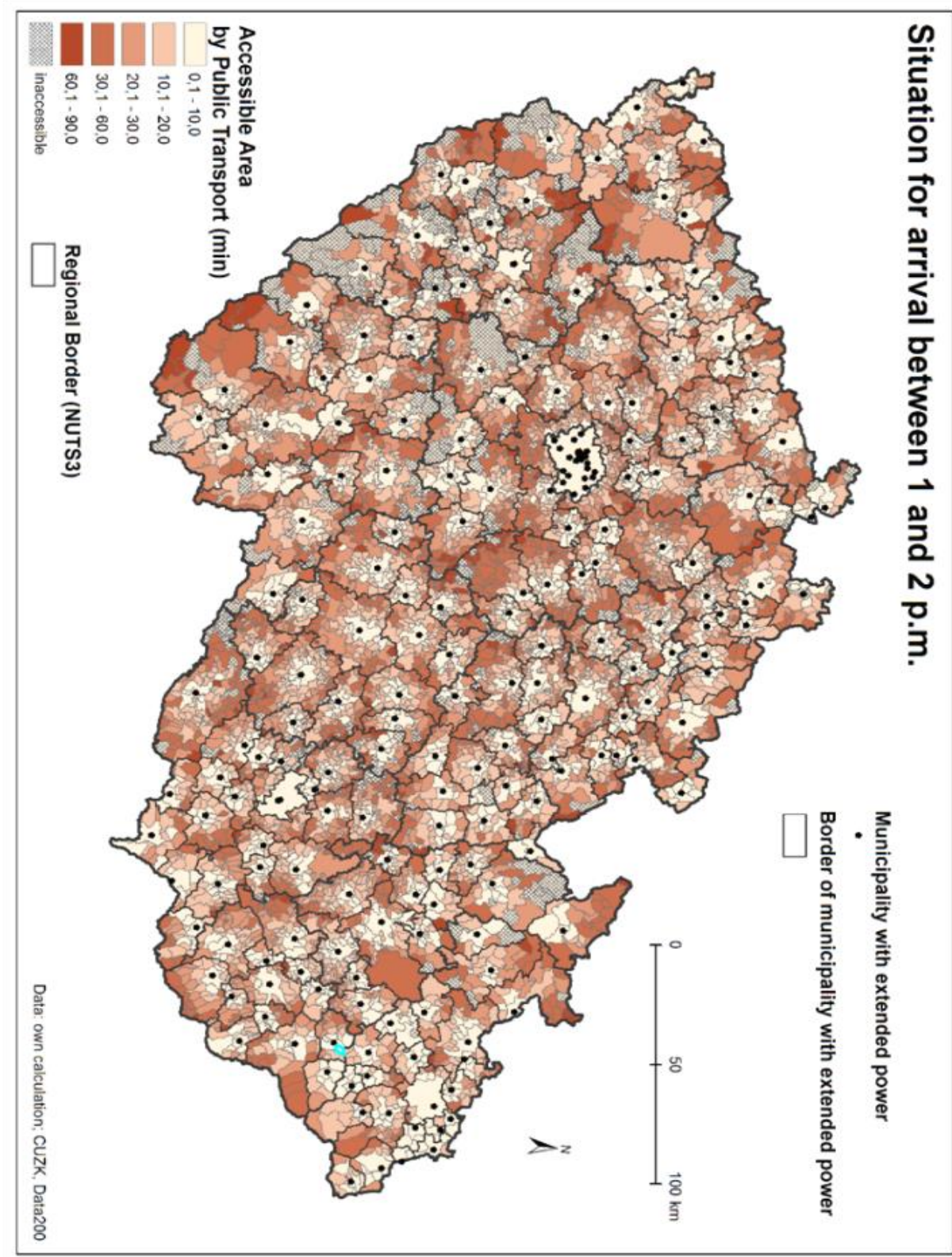

Source: Authors 
Figure 7: Accessibility of MEPs' offices by public transport between 1 and 2 p.m.

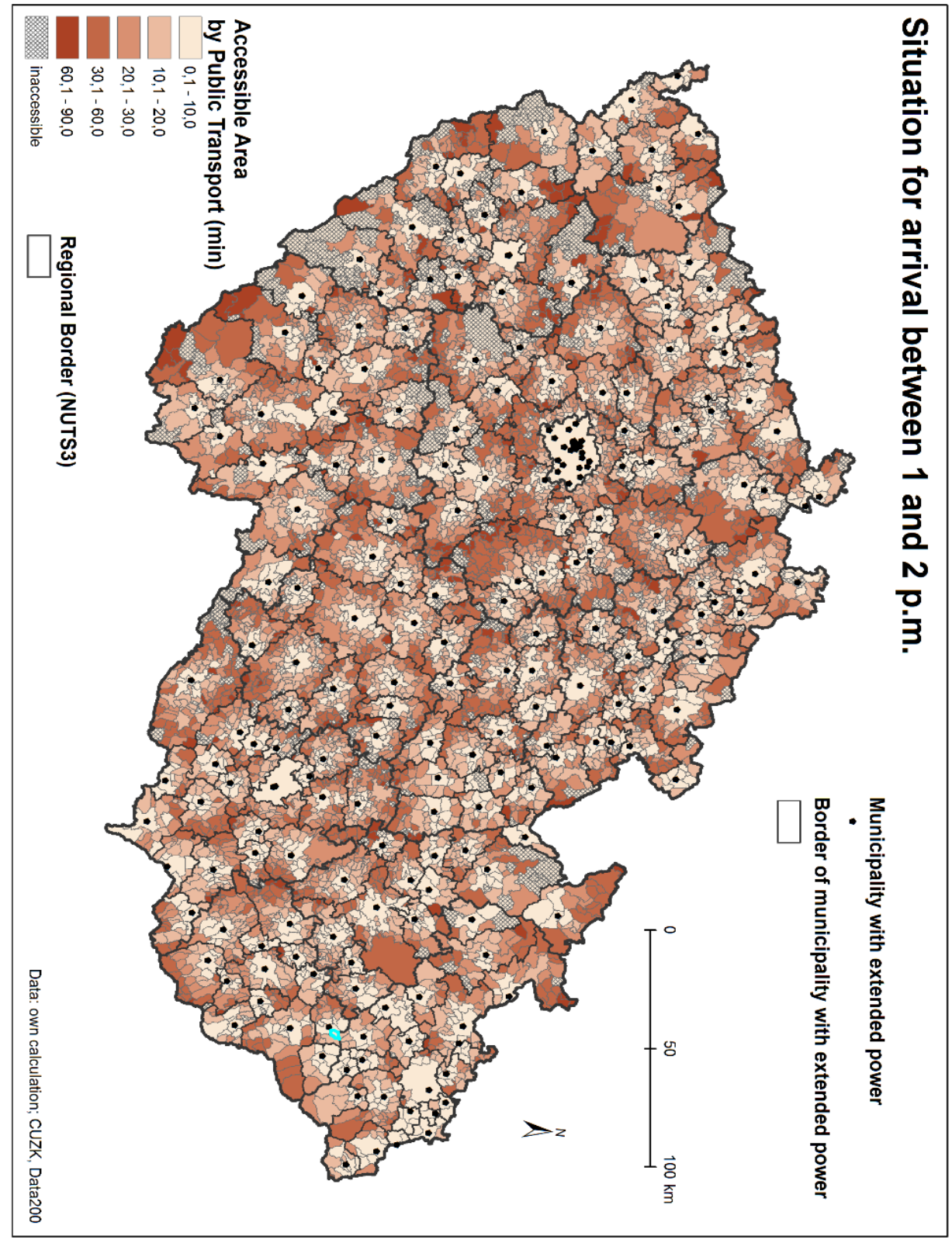

Source: Authors 
A summary of the MEPs' office accessibility via public transport, in both the morning and afternoon hours, is shown in Table 2. The level of accessibility is related to the population of the MEP's administrative district aged 15+ (this age group is assumed to represent those needing to communicate with the MEP authorities). According to the Czech Statistical Office, as of 1 January 2014 there were 8,934,964 inhabitants aged $15+$ in the Czech Republic. $35 \%$ of these inhabitants live in the areas served by Group I MEPs, and 30\% in districts served by MEPs in Group II; $16 \%$ are served by Group III MEPs, $12 \%$ by Group IV and $7 \%$ by Group V.

Table 2 Level of public transport accessibility per MEP group, by proportion of population aged $15+$, morning and afternoon.

\begin{tabular}{|c|c|c|c|c|c|c|c|}
\hline \multirow{2}{*}{\multicolumn{2}{|c|}{ Level of accessibility }} & \multicolumn{6}{|c|}{ Groups of MEPs according to the size of their administrative district } \\
\hline & & I. & II. & III. & IV. & V. & All MEPs \\
\hline \multicolumn{2}{|c|}{$\begin{array}{l}\text { Number of inhabitants aged } \\
15+\text { in MEP group } \\
(1 / 1 / 2014)\end{array}$} & 3122789 & 2658167 & 1405099 & 1105382 & 643527 & 8934964 \\
\hline \multirow{2}{*}{ Excellent } & 6 to 8 am & $84.9 \%$ & $56.7 \%$ & $60.9 \%$ & $62.0 \%$ & $66.7 \%$ & $68.6 \%$ \\
\hline & 1 to $2 \mathrm{pm}$ & $84.1 \%$ & $55.0 \%$ & $57.0 \%$ & $58.4 \%$ & $64.5 \%$ & $66.6 \%$ \\
\hline \multirow{2}{*}{ Very good } & 6 to 8 am & $8.0 \%$ & $20.8 \%$ & $18.4 \%$ & $20.6 \%$ & $20.7 \%$ & $15.9 \%$ \\
\hline & 1 to $2 \mathrm{pm}$ & $7.4 \%$ & $19.5 \%$ & $19.4 \%$ & $20.5 \%$ & $18.2 \%$ & $15.3 \%$ \\
\hline \multirow{2}{*}{ Good } & 6 to 8 am & $4.4 \%$ & $12.3 \%$ & $10.2 \%$ & $10.1 \%$ & $8.3 \%$ & $8.6 \%$ \\
\hline & 1 to $2 \mathrm{pm}$ & $4.6 \%$ & $12.1 \%$ & $10.0 \%$ & $10.3 \%$ & $8.6 \%$ & $8.7 \%$ \\
\hline \multirow{2}{*}{ Poor } & 6 to 8 am & $2.7 \%$ & $9.4 \%$ & $9.4 \%$ & $6.8 \%$ & $3.9 \%$ & $6.3 \%$ \\
\hline & 1 to $2 \mathrm{pm}$ & $3.4 \%$ & $10.7 \%$ & $10.1 \%$ & $6.1 \%$ & $4.2 \%$ & $7,0 \%$ \\
\hline \multirow{2}{*}{ Very poor } & 6 to 8 am & $0.0 \%$ & $0.7 \%$ & $0.9 \%$ & $0.3 \%$ & $0.3 \%$ & $0.4 \%$ \\
\hline & 1 to $2 \mathrm{pm}$ & $0.1 \%$ & $0.9 \%$ & $1.6 \%$ & $0.9 \%$ & $1.2 \%$ & $0.7 \%$ \\
\hline \multirow{2}{*}{ Inaccessible } & 6 to 8 am & $0.1 \%$ & $0.1 \%$ & $0.2 \%$ & $0.2 \%$ & $0.0 \%$ & $0.1 \%$ \\
\hline & 1 to $2 \mathrm{pm}$ & $0.4 \%$ & $1.7 \%$ & $2.0 \%$ & $3.9 \%$ & $3.2 \%$ & $1.7 \%$ \\
\hline
\end{tabular}

Source: Authors, CZSO.

Residents living in districts served by the 15 MEPs of group I are in the best situation for accessing their authorities by public transport. For the remaining 190 MEPs, accessibility is poorer, but comparable for the majority of the population.

\section{Discussion}

The results of our efficiency evaluation using an FDH model clearly demonstrate that most MEPs are inefficient. The FDH model was used because it does not produce relative results on levels of efficiency, as DEA models would. MEPs in the Czech 151 
Republic represent highly varied production units in terms of the sizes of populations they serve, and so a relative result would not tell us very much. For the same reason, the values of the variables selected for both the input and the output in our model were recalculated per inhabitant of each MEP's administrative district. The results of this analysis reveal certain gaps in the MEPs' efficiency, not only on the expenditure side in the form of the MEPs' operating expenditures, but also in terms of the administrative fee revenues the MEPs collect and the state contributions they receive in return for performing state administrative tasks. These state contributions are calculated using statutorily established algorithms (Act No. 475/2013) which take into account the population of the MEP's administrative centre and administrative district, and which are set up such that they discriminate against larger MEPs and in favour of smaller ones (see Figure 2). We can therefore assume that the average difference in contribution per inhabitant of the administrative district, within the surveyed groups, at level of $35 \%$ had a significant influence on the results of the efficiency test, especially for MEPs belonging to Group II.

The managers of MEPs performing delegated state administrative tasks can influence, to a limited extent, the operating costs of doing so, but have significantly less ability to affect the administrative fee revenues the MEP collects in return for such services, and cannot influence the state contribution they receive at all, unless the population of their $\mathrm{AD}$ or $\mathrm{AC}$ increases, or their poor exercise of such tasks leads to sanctions being imposed by the supervisory authorities. Kuntorádová (2015) discusses these state contributions and draws attention to municipalities' financing gaps, and the Strategic Framework of the Development Public Administration in the Czech Republic for 20142020 points to inefficiency and non-transparency in the allocation of financing to cover costs related to public governance.

If accessibility is viewed in terms of journey time to reach the MEP's offices, we must not only consider the area served by the MEP and its accessibility in terms of journey time intervals (see maps on Figure 6 and Figure 7), but also the population density in the MEP's administrative district. The population is most densely concentrated in district capitals and their surroundings. Logically, the greater the proportion of the total district population is living in the MEP's administrative centre, the greater number of inhabitants will have excellent accessibility to the MEP's offices. This is particularly noticeable in the case of Brno and Ostrava MEPs, which differ significantly from the other 203 MEPs in terms of population. The results of our public transport journey time assessment (see Table 2) show that MEP offices are within excellent reach for $68.6 \%$ of the population in the morning hours and for $66.6 \%$ of the population in the afternoon hours. For a further $30 \%$ of the population accessibility is very good, good or poor. However, for $2 \%$ of the population accessibility is very poor or the MEP offices are considered inaccessible based on our criteria. The MEP offices' level of public transport accessibility is influenced by the offices' location, the size of the administrative district and the provision of public transport.

It is important to remember that unlike schools or healthcare facilities, MEP authorities are not institutions that citizens regularly and systematically visit. Attending their offices is usually for a specific purpose (e.g. to obtain or renew identity cards, passports, 
driving licences, business licences), and such visits can be adjusted to fit with public transport services, or indeed another means of transportation can be used. Furthermore, a number of delegated state administrative services are provided by individual municipal authorities (at a more local level than MEPs); these include matters relating to the land registry and building regulations).

The MEPs studied in this paper include seven MEPs that receive an increased state contribution in return for their performance of delegated state administrative tasks. In the cases of Brno, Ostrava and Plzeñ this additional contribution is because the MEPs in question exercised extended competences prior to 2003. In the cases of Šlapanice, Černošice, Nýřany and Brandýs nad Labem - Stará Boleslav this is based on Act No. 314/2002, which established that the MEPs' offices would be partially located outside MEP's administrative centre and assumes that as a result, these municipalities will spend more on office operations. However, our FDH model analysis showed that in 2014 these municipalities' operating expenses were sufficiently low that they did not warrant any additional state contribution compared to other MEPs. We cannot draw definite conclusions from this given that our analysis was based only on data from one year, yet it would be appropriate to consider whether the additional contribution of $30,535,976$ CZK $(4 \times 7,633,994)$ from the State Budget to these municipalities is efficient and whether it is fair to the other MEPs. The extra contribution was no doubt legitimate in the early years of these MEPs operating remote sites, but our analysis suggests that this may no longer be relevant. Furthermore, our public transport accessibility analysis shows that these MEPs' offices' accessibilty did not become any better after being relocated to a different town.

Our results cannot demonstrate any direct links between MEPs' efficiency and accessibility. Several MEPs which have excellent accessibility across their administrative district - Český Těšín, Orlová, Bohumín and Karviná - were shown to operate inefficiently by the FDH model analysis. Meanwhile, many MEPs with poor accessibility are efficient, including Šlapanice, Černošice, Nýřany and Hustopeče. Poor accessibility does not necessarily equate to higher operating expenses for the authority although we might expect this poor accessibility to affect the authorities' employees' travel expenses. Poor accessibility does, though, have a direct impact on the population living within the administrative district, who are burdened with increased transportation expenses and lose more time travelling to the MEP offices.

\section{Conclusion}

This paper has evaluated, using an output-oriented FDH model, the efficiency of the state contribution to MEPs for their performance of delegated state administrative tasks, and of administrative fee revenues collected by MEPs, for all 205 municipalities with extended powers, relative to the MEPs' operating expenses as of 31 December, 2014. The results are presented for to five groups of MEPs, based on the population of their administrative districts; these are detailed in Chapter 3 of this paper. The largest number (12) of efficient MEPs is identified in the group containing the 15 largest MEPs, while the smallest number (6) of efficient MEPs is found in the second size group consisting of 45 large MEPs. Overall, only 66 out of 205 MEPs are efficient. This result is 153 
primarily affected by MEPs' operating expenses and the level of state contribution the MEPs receive. Efficiency is influenced less significantly by the MEPs' administrative fee revenues.

This paper has also evaluated the MEP offices' public transport accessibility; this was analysed for two time intervals $-6: 00$ to 8:00 am and 1:00 to 2:00 pm - on a working day. The degree of accessibility is defined by journey time intervals. Excellent accessibility (journey time max. 10 minutes) was found in the morning hours for $68.6 \%$ of the national population aged 15+; many of these inhabitants are served by the 15 largest MEPs. Poor accessibility (a journey of over 60 minutes) was found primarily in the afternoon hours and affects approximately $2 \%$ of the population aged $15+$. The accessibility levels are reported for the same five MEP size groups used in the efficiency evaluation, which are detailed in Chapter 3 of this article.

Special attention is paid to seven MEPs which have a special status. Four of these (Šlapanice, Černošice, Nýřany and Brandýs nad Labem - Stará Boleslav), receive an increased state contribution due to having their main office located in another town; our analysis shows that this extra contribution is not necessary for their efficient operation.

The effectiveness and accessibility of public administration go hand in hand; this paper has pointed out possible connections and links in this area that are crucial when systemic and strategic changes are considered at Government level. The results presented in this paper can be used in designing new models for financing delegated state administrative services, especially related to specific objective 2.4 of the Strategic Framework of the Development Public Administration in the Czech Republic for 20142020.

Acknowledgements: This article was supported within "Operational Programme Education for Competitiveness - Project No. CZ.1.07/2.3.00/20.0296" and by the Czech Science Foundation, Project No. 14-26831S.

Disclosure statement: No potential conflict of interest was reported by the author.

\section{References}

Act No. 314/2002 Coll., on Establishment of Municipalities with Authorised Municipal Offices and on Establishment of Municipalities with Extended Powers, as last amended.

Act No. 634/2004 Coll., on administrative fees, as last amended.

Act No. 475/2013 Coll., on the State Budget of the Czech Republic for 2014.

Act No. 250/2000 Coll., on budgetary rules of territorial budgets, at last amended.

BORŮVKOVÁ, J., \& KUNCOVÁ, M. (2012). Porovnání očních oddělení nemocnic Kraje Vysočina pomocí DEA modelů. Acta Oeconomica Pragensia, 12 (5), 75-84. DOI: $\underline{10.18267 / j . a o p .382}$ 
Chamber of Deputies Parliament of the Czech Republic. Usnesení č. 304 výboru pro veřejnou správu, regionální rozvoj a životní prostředí z 59. schůze ze dne 27. února 2002. Retrieved January 14, 2015, from http://www.psp.cz

CZSO. (2015). Small Lexicon of Municipalities of the Czech Republic. Retrieved December 10, 2014 from https://www.czso.cz/csu/czso/maly-lexikon-obci-ceskerepubliky-2014-n-gdc2kaznu1

Degree of Ministry of Interior of the Czech Republic No. 388/2002 Coll., on Establishment of Administrative Districts of Minucipalities with Authorised Municipal Offices and on Establishment of Administrative Districts of Municipalities with Extended Powers.

DEPRINS, D., \& SIMAR, L., \& TULKENS, H. (1984). Measuring labor efficiency in Post offices. In: Marchand, M., Pestieau, P., Tulkens, H. (eds.): The Performance of Public Enterprises: Concepts and Measurement. Amsterdam: North-Holland, 243-267.

DLOUHÝ, M., \& JABLONSKÝ, J., \& NOVOSÁDOVÁ, I. (2007). Využití analýzy obalu dat pro hodnocení efektivnosti českých nemocnic. Politická ekonomie, 54 (1), 6071. DOI: $10.18267 /$ j.polek.590

DLOUHÝ, M. (2009). Efficiency and productivity analysis in health services. Prague Economic Paper, 18 (2), 176-184. DOI: 10.18267/j.pep.348

DRDLA, P. (2014). Osobní doprava regionálního a nadregionálního významu. Univerzita Pardubice, 412 s.

HAY, A. (2000). Transport geography. In Johnston, R. J., \& Gregory, D., \& Pratt, G., \& Watts, M. (Eds.): The Dictionary of Human Geography (pp. 855-856). Oxford: Blackwell Publishers.

HENDRYCH, D., \& KAVĚNA, M., \& PAVLÍK, M. (2014). Správní věda. Teorie veřejné správy. 4., aktualiz. a dopl. vyd. Praha: Wolters Kluwer.

HORÁK, J., IVAN, I., FOJTÍK, D., \& BURIAN, J. (2014). Large scale monitoring of public transport accessibility in the Czech Republic. Proceedings of the 15th International Carpathian Control Conference, ICCC 2014. 157-163.

IVAN, I., \& HORÁK, J. (2015). Demand and Supply of Transport Connections for Commuting in the Czech Republic. In: Ivan, I., Benenson, I., Jiang, B., Horák, J., Haworth, J., \& Inspektor, T. (2015). Geoinformatics for Intelligent Transportation. Lecture Notes in Geoinformation and Cartography, Springer, 214, 137-147.

JABLONSKÝ, J., \& DLOUHÝ, M. (2004). Modely hodnocení efektivnosti produkčních jednotek. Praha: Professional Publishing.

JABLONSKÝ, J., \& GRMANOVÁ, E. (2009). Analýza efektívnosti slovenských a českých poist'ovní pomocou modelov analýzy obalu dát. Ekonomický časopis, 57 (9), 857-869. 
JACOBS, R. (2001). Alternative methods to examine hospital efficiency: data envelopment analysis and stochastic frontier analysis. Health Care Management Science, 4 (2), 103-115. DOI: 10.1023/A:1011453526849

KUNTORÁDOVÁ, I. (2015). Politické aspekty financování českých měst. Praha: Univerzita Karlova v Praze.

Ministry of Interior of the Czech Republic. (2012). Analýza aktuálního stavu veřejné správy. Retrieved January 16, 2015, from http://www.mvcr.cz/clanek/analyzaaktualniho-stavu-verejne-spravy.aspx

Ministry of Interior of the Czech Republic. (2015). Strategický rámec rozvoj veřejné správy České republiky pro obdobi 2014-2020. Retrieved February 15, 2015, from http://www.mvcr.cz/clanek/strategicky-ramec-rozvoje.aspx

Ministry of Finance of the Czech Republic. (2015). Monitor. [online]. Retrieved January 17, 2015, from http://monitor.statnipokladna.cz/2014/

MUDRYCH, P. (1998). Ranní dopravní špička jako základ pro studium geografických souvislostí v zázemí našich středisek. Geografie. 428-436.

PROVAZNÍKOVÁ, R., \& PETR, P. (2014). The Aspects of Financing of Municipalities with Extended Power. In D. Špalková \& Matějová, L. (Ed.), Current Trends in Public Sector Research (pp. 68-75). Šlapanice: Masarykova univerzita.

SIMPSON, H. (2009). Productivity in Public Services. Journal of Economic Surveys, 23 (2), 250-276. DOI: 10.1111/j.1467-6419.2008.00562.x

TOTH, P. \& et al. (2009). Financial Analysis of Local administration and Govermnet in the Czech Republic. Praha: Vysoká škola ekonomická v Praze. [online]. Retrieved February 17, 2015, from http://www.vse.cz

VAKKURI, J. (2003). Research Techniques and Their Use in Managing Non Profit Organisations. An Illustration of DEA Analysis in NPO Environments. Financial Accountability \& Management, 19 (3), 243-264.

VAŇKOVÁ, I., \& VRABKOVÁ, I. (2014). The Factors Influencing Economic Efficiency of the Hospital Bed Care in Terms of the Regional Allowance Organizations. Národohospodářský obzor, 14 (3), 233-248. DOI: 10.2478/revecp-2014-0012 